\title{
https://fungalgenera.org/: a comprehensive database providing web- based information for all fungal genera
}

\section{Monkai $\mathrm{J}^{1}$, McKenzie $\mathrm{EHC}^{2}$, Phillips $\mathrm{AJL}^{3}$, Hongsanan $\mathrm{S}^{4}$, Pem $\mathrm{D}^{1,5}$, Liu $\mathrm{JK}^{6}$, Chethana KWT ${ }^{1,7 *}$, Tian $\mathbf{Q}^{1}$, Ekanayaka $\mathrm{AH}^{1}$, Lestari $\mathrm{AS}^{1,8}$, Zeng $\mathrm{M}^{1,9}$, Zhao $\mathbf{Q}^{9}$, Norphanphoun $\mathrm{C}^{1}$, Abeywikrama $\mathbf{P D}^{1,10}$, Maharachchikumbura $\mathrm{SSN}^{6}$, Jayawardena RS ${ }^{1,7}$, Chen Y $J^{1}$, Zhao R-L ${ }^{11,12}$, He M-Q ${ }^{11}$, Raspé ${ }^{1,7}$, Kirk PM ${ }^{13}$, Gentekaki $\mathrm{E}^{7}$, and Hyde $\mathrm{KD}^{1,9}$}

${ }^{1}$ Center of Excellence in Fungal Research, Mae Fah Luang University, Chiang Rai, Thailand

${ }^{2}$ Landcare Research-Manaaki Whenua, Private Bag 92170, Auckland, New Zealand

${ }^{3}$ Faculdade de Ciências, Biosystems and Integrative Sciences Institute (BioISI), Universidade de Lisboa, Campo Grande, 1749-016 Lisbon, Portugal

${ }^{4}$ College of Life Science and Oceanography, Shenzhen University, 1068, Nanhai Avenue, Nanshan, Shenzhen 518055, P.R. China

${ }^{5}$ Department of Biology, Faculty of Science, Chiang Mai University, Chiang Mai 50200, Thailand

${ }^{6}$ School of Life Science and Technology, University of Electronic Science and Technology of China, Chengdu 611731, P.R. China

${ }^{7}$ School of Science, Mae Fah Luang University, Chiang Rai, Thailand

${ }^{8}$ Research Center for Biomaterials, Indonesian Institute of Sciences (LIPI), JL. Raya Bogor km.46, Cibinong, Bogor, Jawa Barat, Indonesia

${ }^{9}$ Key Laboratory for Plant Diversity and Biogeography of East Asia, Kunming Institute of Botany, Chinese Academy of Sciences, Kunming 650201, P.R. China

10 Institute of Plant and Environment Protection, Beijing Academy of Agriculture and Forestry Sciences, No.9 of Shuguanghuayuanzhonglu, Haidian District, Beijing 100097, P.R. China

${ }^{11}$ State key laboratory of Mycology, Institute of Microbiology, Chinese Academy of Sciences, Beijing, 100101, P.R. China

${ }^{12}$ College of Life Sciences, University of Chinese Academy of Sciences, Huairou District, Beijing, 100408, P.R. China

${ }^{13}$ Royal Botanic Gardens, Kew, Richmond, Surrey TW9 3DS, UK

Monkai J, McKenzie EHC, Phillips AJL, Hongsanan S, Pem D, Liu JK, Chethana KWT, Tian Q, Ekanayaka AH, Lestari AS, Zeng M, Zhao Q, Norphanphoun C, Abeywikrama PD, Maharachchikumbura SSN, Jayawardena RS, Chen YJ, Zhao R-L, He M-Q, Raspé O, Kirk PM, Gentekaki E, Hyde KD 2019 - https://fungalgenera.org/: a comprehensive database providing webbased information for all fungal genera. Asian Journal of Mycology 2(1), 298-305, Doi 10.5943/ajom/2/1/20

\begin{abstract}
Maintaining and updating databases and checklists of genera of fungi is an essential task for most fungal research. Advances in molecular techniques in the last 20 years have greatly influenced the fungal taxonomy and classification. Consequently, it is important to have access to all existing data and for these data to be continuously updated with recent changes. To address this issue, a website: https://fungalgenera.org/, was established in 2017 and introduced in this paper. This website provides basic information and links to data for all fungal genera with easily accessible and searchable functions.
\end{abstract}


Keywords - Database - Genera of fungi - Phylogeny - Taxonomy

\section{Introduction}

Fungal taxonomy is an integral part of fungal research. The importance of fungal taxonomy is evident in biodiversity and conservation, environmental monitoring, agriculture biotechnology and bioprospecting (Jayasiri et al. 2015, Hyde et al. 2019c). In the past decade, the knowledge of taxonomy and classification of fungi have advanced significantly. This is mainly due to the improvement and widespread application of molecular techniques used to study the fungal phylogeny and delineate species and relationships among taxa (Seifert et al. 2011). A combination of morphological and DNA sequence data has been successfully used to resolve new genera and species (Rossman \& Palm-Hernández 2008). Changes outlined in the International Code of Nomenclature for algae, fungi, and plants (ICN) in 2012 has led to the end of the dual nomenclature for pleomorphic fungi (Hawksworth 2011). This has resulted in the publication of a list of protected fungal generic names (Kirk et al. 2013), which was later adopted and published in the Shenzhen Code 2018 (Turland et al. 2018).

Taxa are delineated and defined based on morphology and DNA sequence data, in combination with ecological data, which may include life-styles, host association and geographical distribution (Norphanphoun et al. 2018, Perera et al. 2018, Tsai et al. 2018, Chuankid et al. 2019, de Silva et al. 2019, Pem et al. 2019). Many comprehensive phylogenetic studies on fungi at the higher level have led to major progress in taxonomic classification (Hyde et al. 2013, Wang et al. 2014, 2015a, b, Liu et al. 2015, Maharachchikumbura et al. 2015, 2016, Zhao et al. 2017, He et al. 2019, Hyde et al. 2019a, Phillips et al. 2019). Several genera were discovered to be polyphyletic, and their taxonomic placement has been resolved (Seifert et al. 2011, Hyde et al. 2013, Johnston et al. 2014, Wijayawardene et al. 2014, 2017b, Maharachchikumbura et al. 2015, 2016, Senanayake et al. 2015, Ekanayaka et al. 2017, 2018, Daranagama et al. 2018, Dayarathne et al. 2019, Lu et al. 2018). Many novel genera and species have been introduced in recent years (Doilom et al. 2018, Hyde et al. 2018, Niskanen et al. 2018, Hyde et al. 2019b, Khmelnitsky et al. 2019, Phookamsak et al. 2019, Vadthanarat et al. 2019). Therefore, a stable platform to maintain up-to-date information for all fungal genera is needed as it is an important basis for all future taxonomic studies.

\section{The need for fungal genera database}

Databases have the role of bringing data together, and online databases have become major tools for obtaining information worldwide. Current taxonomic studies have been expanded through numerous fungal databases, which provide valuable sources to find existing information concerning fungi (e.g. Jayasiri et al. 2015). The key taxonomic and nomenclatural databases of fungi include Index Fungorum, Species Fungorum and MycoBank. The NCBI, EBI and UNITE databases have been used to link DNA sequence data with fungal taxa.

Some of these databases, however, lack up-to-date information according to recent nomenclatural and taxonomic changes from various studies and none are not linked together (e.g. Hyde et al. 2013, 2019a, Wijayawardene et al. 2014, Senanayake et al. 2015, Maharachchikumbura et al. 2015, 2016, He et al. 2019). There have been several attempts to publish outlines that compile all existing data for Ascomycota and their asexual genera (Lumbsch \& Huhndorf 2010, Hyde et al. 2011, Wijayawardene et al. 2012, 2017a, b, 2018a, b, Kirk et al. 2013, Jaklitsch et al. 2016, Ekanayaka et al. 2017, Hongsanan et al. 2017, Hyde et al. 2017, Liu et al. 2017, Lücking et al. 2017). Each published article, however, only provides a snapshot of the accepted taxonomy and nomenclature at the time of writing. It is essential to bring all these information together in a comprehensive database that is continuously updated. While Face of Fungi database has a role to deposit and provide comprehensive metadata of fungi, it mainly focuses on the species level. Therefore, this website will provide more details with the emphasis on genera.

\section{The website: https://fungalgenera.org/}

This website provides basic data and links to data for all genera of fungi. The purpose of the 
site is to (1) provide a search facility to the notes and up-to-date classification of all accepted genera of fungi which includes the main fungal groups (Ascomycota, Basidiomycota, basal fungi), (2) maintain updated databases and higher classification of fungal genera and (3) supply links to all the important data of fungal genera including a list of recent publications.

Notes concerning placement and status are provided for each genus. These include classification, type species, the number of accepted species, life modes, geographic distribution, and culture and sequence availability. Links to online databases and recently published data are also provided. We will further expand the information of each genus, with descriptions, photographic plates, phylogenetic trees, keys to genera and other important data through the links from other related webpages (Face of Fungi: http://www.facesoffungi.org/, One Stop Shop: https://onestopshopfungi.org/, Marine fungi: http://marinefungi.org/) and other upcoming webpages (Basidiomycota fungi: http://www.basidio.org/, Freshwater fungi: http://freshwaterfungi.org/). The fungal genera database will enhance better understanding of fungal genera and allow mycologists to gain new insights into updated fungal taxonomy and classification. This webpage is user-friendly, and facilitates easy access to relevant information and easy search for genera.

\section{Construction}

All fungal genera in the database are listed according to the most recent classifications of Ascomycota (Wijayawardene et al. 2017a, 2018a), Basidiomycota (He et al. 2019), and basal fungi (=lower fungi) (Wijayawardene et al. 2018c). The database will be updated regularly to include new information on genera of fungi as they become available.

\section{Database interface and visualization}

The website incorporates several functions with a simple and user-friendly interface. The homepage provides a general introduction to the database (Fig. 1). There are two options to find information on fungal genera: (1) use the search box at the top of the homepage (Fig. 2) or (2) select the phyla listed in the menu bar of the homepage ("Ascomycota", "Basidiomycota" and "Lower fungi”). Each phylum contains a scroll down menu listing classes, families and genera (Fig. 3). Clicking on the genus name reveals data on the genus. Each entry provides important information on the genus and links to other webpages (Fig. 4). We have invited international curators with expertise in various groups of fungi to continuously monitor the webpages and to suggest improvements (Table 1). Other interested parties can contact the moderator with their suggestions, or they can offer their service as curators.

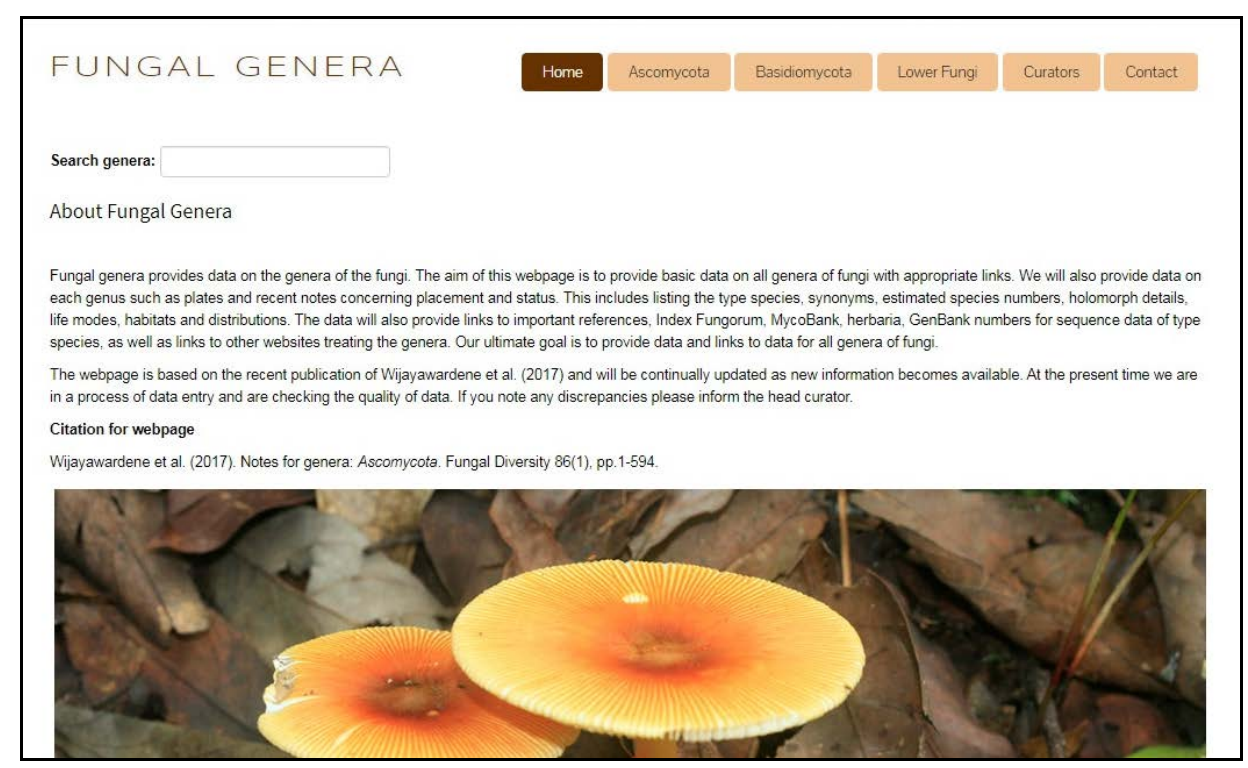

Fig. 1 - The homepage view of fungal genera database 


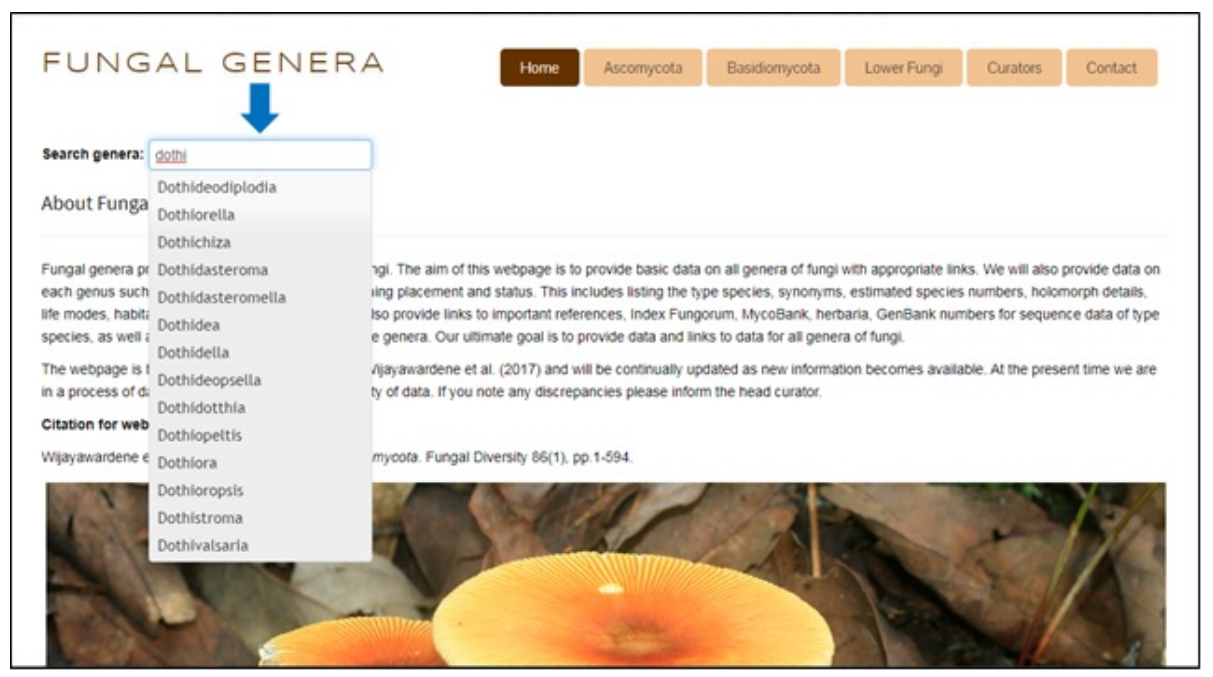

Fig. 2 - The use of search box to find the information of genera

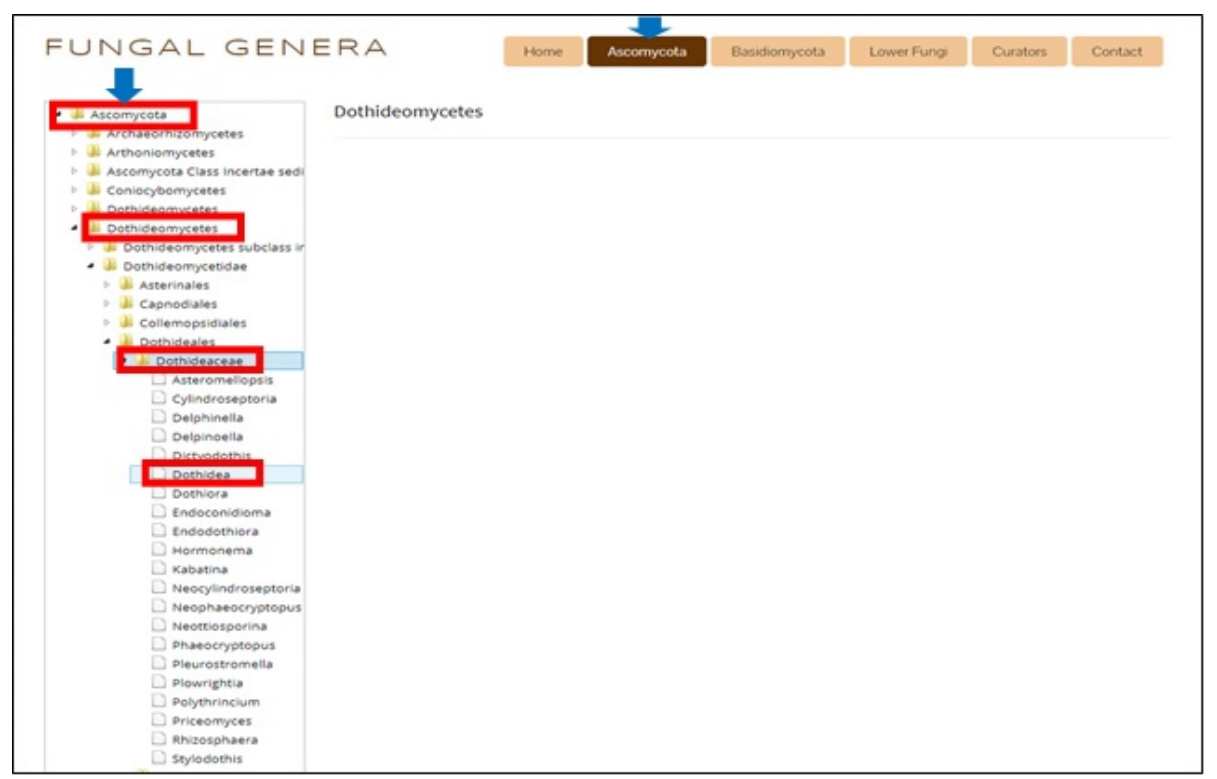

Fig. 3 - A scroll down list of phyla, classes, families and genera

\begin{tabular}{|c|c|c|c|c|c|c|c|}
\hline \multicolumn{2}{|c|}{ FUNGAL GENERA } & Home & Ascomycota & Basidiomycota & Lower Fungi & Curators & Contact \\
\hline 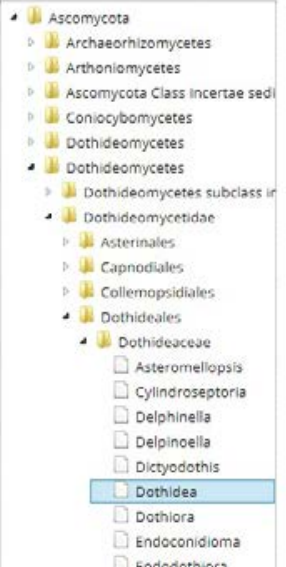 & 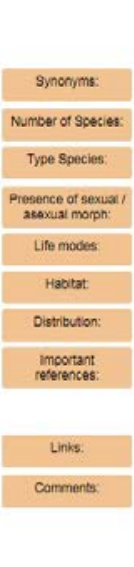 & $\begin{array}{l}\text { = Phragmodot } \\
\text { around } 500 \mathrm{spt} \\
\text { Dotnidea samb } \\
\text { asexual morph } \\
\text { saprobes } \\
\text { terrestrial, aque. } \\
\text { worldwide } \\
\text { Lumbsch and } \\
\text { Kirk et al. (201 } \\
\text { Wijayawarden } \\
\text { Indexfungoru } \\
\text { extype strains }\end{array}$ & $\begin{array}{l}\text { Andorf (2010: ou } \\
\text { enus accepted), } \\
\text { tal. (2014C: outl } \\
\text { MycoBank, Gent } \\
\text { ype DAOM } 2313\end{array}$ & $\begin{array}{l}\text { Dothidea } \\
\text { ol. (Havniae) 2: } \\
\text { = = Systremma The } \\
\text { (species could be }\end{array}$ & $\begin{array}{l}\text { morphologyy. } \\
\text { a: morphology }\end{array}$ & ylogeny). & m 2017 \\
\hline
\end{tabular}

Fig. 4 - Information on each genus with links to access important references and databases 
Table 1 Fungal groups and curators

\begin{tabular}{ll}
\hline Fungal Group & Curators \\
\hline Ascomycota & Kevin D. Hyde \\
& Eric H. C. McKenzie \\
Dothideomycetes & Alan J. L. Phillips \\
& Sinang Hongsanan \\
& Dhandevi Pem \\
& Jian-Kui Liu \\
& K. W. Thilini Chethana \\
Eurotiomycetes & Qing Tian \\
Leotiomycetes & Anusha H. Ekanayaka \\
& Anis Lestari \\
Pezizomycetes & Ming Zeng \\
& Qi Zhao \\
Sordariomycetes & Chada Norphanphoun \\
& Pranami Abeywickrama \\
& Sajeewa S. N. Maharachchikumbura \\
& Ruvishika S. Jayawardena \\
Basidiomycota & Yi-Jyun Chen \\
& Rui-Lin Zhao \\
Basal fungi & Mao-Qiang He \\
& Olivier Raspé \\
& Paul M Kirk \\
\hline
\end{tabular}

\section{Acknowledgements}

This work was financed by the Mushroom Research Foundation (MRF), Thailand. Alan JL Phillips acknowledges the support from UID/MULTI/04046/2019 Research Unit grant from FCT, Portugal to BioISI.

\section{References}

Chuankid B, Vadthanarat S, Hyde KD, Thongklang N et al. 2019 - Three new Phylloporus species from tropical China and Thailand. Mycological Progress 18(5), 603-614.

Daranagama DA, Hyde KD, Sir EB, Thambugala KM et al. 2018 - Towards a natural classification and backbone tree for Graphostromataceae, Hypoxylaceae, Lopadostomataceae and Xylariaceae. Fungal Diversity 88, 1-165.

Dayarathne MC, Maharachchikumbura SS, Jones EB, Wei D et al. 2019 - Phylogenetic revision of Savoryellaceae and evidence for its ranking as a subclass. Frontiers in Microbiology 10, 840.

de Silva NI, Phillips AJ, Liu JK, Lumyong S et al. 2019 - Phylogeny and morphology of Lasiodiplodia species associated with Magnolia forest plants. Scientific reports 9(1), 1-11.

Doilom M, Hyde KD, Phookamsak R, Dai DQ et al. 2018 - Mycosphere Notes 225-274: types and other specimens of some genera of Ascomycota. Mycosphere 9, 647-754.

Ekanayaka AH, Ariyawansa HA, Hyde KD, Jones EB et al. 2017 - Discomycetes: the apothecial representatives of the phylum Ascomycota. Fungal Diversity 87, 237-298.

Ekanayaka AH, Hyde KD, Jones EG, Zhao Q et al. 2018 - Taxonomy and phylogeny of operculate discomycetes: Pezizomycetes. Fungal Diversity 90, 161-243.

Hawksworth DL. 2011 - A new dawn for the naming of fungi: impacts of decisions made in Melbourne in July 2011 on the future publication and regulation of fungal names. MycoKeys 1, 7-20.

He MQ, Zhao RL, Hyde KD, Begerow D et al. 2019 - Notes, outline and divergence times of Basidiomycota. Fungal Diversity 1-263. Doi: 10.1007/s13225-019-00435-4. 
Hongsanan S, Maharachchikumbura SS, Hyde KD, Samarakoon MC et al. 2017 - An updated phylogeny of Sordariomycetes based on phylogenetic and molecular clock evidence. Fungal Diversity 84, 25-41.

Hyde KD, Chaiwan N, Norphanphoun C, Boonmee S et al. 2018 - Mycosphere notes 169-224. Mycosphere 9, 271-430.

Hyde KD, Jones EBG, Liu JK, Ariyawansa H et al. 2013 - Families of Dothideomycetes. Fungal Diversity 63, 1-313.

Hyde KD, Maharachchikumbura SS, Hongsanan S, Samarakoon MC et al. 2017 - The ranking of fungi: a tribute to David L. Hawksworth on his 70th birthday. Fungal Diversity 84, 1-23.

Hyde KD, McKenzie EHC, Koko TW. 2011 - Towards incorporating anamorphic fungi in a natural classification - checklist and notes for 2010. Mycosphere 2, 1-88.

Hyde KD, Norphanphoun C, Maharachchikumbura SSN, Bao DF et al. 2019a - The refined families of Sordariomycetes. Mycosphere (in press).

Hyde KD, Tennakoon DS, Jeewon R, Bhat DJ et al. 2019b - Fungal diversity notes 1036-1150: taxonomic and phylogenetic contributions on genera and species of fungal taxa. Fungal Diversity 96(1), 1-242.

Hyde KD, Xu J, Rapior S, Jeewon R. et al. 2019c - The amazing potential of fungi: 50 ways we can exploit fungi industrially. Fungal Diversity 31, 1-36.

Jaklitsch W, Baral HO, Lücking R, Lumbsch HT. 2016 - Ascomycota. In: Frey W (ed) Syllabus of Plant Families, 23rd edn. Borntraeger Science Publishers, Stuttgart.

Jayasiri SC, Hyde KD, Ariyawansa HA, Bhat DJ et al. 2015 - The Faces of Fungi database: fungal names linked with morphology, phylogeny and human impacts. Fungal Diversity 74, 3-18.

Johnston PR, Seifert KA, Stone JK, Rossman AY et al. 2014 - Recommendations on generic names competing for use in Leotiomycetes (Ascomycota). IMA Fungus 5, 91-120.

Khmelnitsky O, Davoodian N, Singh P, Raspé O et al. 2019 - Ionosporus: a new genus for Boletus longipes (Boletaceae), with a new species, I. australis, from Australia. Mycological Progress 18, 439-451.

Kirk PM, Stalpers JA, Braun U, Crous PW. 2013 - A without-prejudice list of generic names of fungi for protection under the International Code of Nomenclature for algae, fungi, and plants. IMA Fungus 4, 381-443.

Liu JK, Hyde KD, Jeewon R, Phillips AJL et al. 2017 - Ranking higher taxa using divergence times: a case study in Dothideomycetes. Fungal Diversity 84, 75-99.

Liu X-Z, Wang QM, Göker M, Groenewald M et al. 2015 - Towards an integrated phylogenetic classification of the Tremellomycetes. Studies in Mycology 81, 85-147.

Lu YZ, Liu JK, Hyde KD, Jeewon R et al. 2018 - A taxonomic reassessment of Tubeufiales based on multi-locus phylogeny and morphology. Fungal Diversity 92, 131-344.

Lücking R, Hodkinson BP, Leavitt SD. 2017 - The 2016 classification of lichenized fungi in the Ascomycota and Basidiomycota-approaching one thousand genera. Bryologist 119, 361-416.

Lumbsch HT, Huhndorf SM. 2010 - Outline of Ascomycota 2009. Myconet 14, 1-64.

Maharachchikumbura SSN, Hyde KD, Jones EBG, McKenzie EHC et al. 2015 - Towards a natural classification and backbone tree for Sordariomycetes. Fungal Diversity 72, 199-301.

Maharachchikumbura SSN, Hyde KD, Jones EBG, McKenzie EHC et al. 2016 - Families of Sordariomycetes. Fungal Diversity 79, 1-317.

Niskanen T, Douglas B, Kirk P, Crous P et al. 2018 - New discoveries: species of fungi described in 2017. In: K. J. Willis (ed.), State of the World's Fungi. Report. Royal Botanic Gardens, Kew. pp. 18-23.

Norphanphoun C, Raspé O, Jeewon R, Wen TC et al. 2018 - Morphological and phylogenetic characterisation of novel Cytospora species associated with mangroves. MycoKeys (38), 93120.

Pem D, Hyde KD, Doilom M, Camporesi E et al. 2019 - Multigene phylogenetic analyses to establish new Valsaria species and taxonomic significance of spore ornamentation. PloS one 14(6), e0217982. 
Perera RH, Maharachchikumbura, SS, Hyde KD, Bhat DJ et al. 2018 - An appendage-bearing coelomycete Pseudotruncatella arezzoensis gen. and sp. nov. (Amphisphaeriales genera incertae sedis) from Italy, with notes on Monochaetinula. Phytotaxa 338(2), 177-188.

Phillips AJ, Hyde KD, Alves A, Liu JKJ. 2019 - Families in Botryosphaeriales: a phylogenetic, morphological and evolutionary perspective. Fungal Diversity 94(1), 1-22.

Phookamsak R, Hyde KD, Jeewon R, Bhat DJ et al. 2019 - Fungal diversity notes 929-1035: taxonomic and phylogenetic contributions on genera and species of fungi. Fungal Diversity 95(1), 1-273.

Rossman AY, Palm-Hernández ME. 2008 - Systematics of plant pathogenic fungi: why it matters. Plant Disease. 92, 1376-1386.

Seifert KA, Morgan-Jones G, Gams W, Kendrick B. 2011 - The genera of Hyphomycetes. CBS Biodiversity Series 9, CBSKNAW Fungal Biodiversity Centre, Utrecht.

Senanayake IC, Maharachchikumbura SSN, Hyde KD, Bhat JD et al. 2015 - Towards unraveling relationships in Xylariomycetidae (Sordariomycetes). Fungal Diversity 73, 73-144.

Tsai I, Maharachchikumbura SS, Hyde KD, Ariyawansa HA. 2018 - Molecular phylogeny, morphology and pathogenicity of Pseudopestalotiopsis species on Ixora in Taiwan. Mycological Progress 17, 941-952.

Turland NJ, Wiersema JH, Barrie FR, Greuter W et al. (eds.) 2018 - International Code of Nomenclature for algae, fungi, and plants (Shenzhen Code) adopted by the Nineteenth International Botanical Congress Shenzhen, China, July 2017. Regnum Vegetabile 159. Glashütten: Koeltz Botanical Books. DOI https://doi.org/10.12705/Code.2018.

Vadthanarat S, Lumyong S, Raspé O. 2019 - Cacaoporus, a new Boletaceae genus, with two new species from Thailand. MycoKeys 54, 1-29.

Wang Q-M, Begerow D, Groenewald M, Liu X-Z et al. 2015a - Multigene phylogeny and taxonomic revision of yeasts and related fungi in the Ustilaginomycotina. Studies in Mycology 81, 55-83.

Wang Q-M, Groenewald M, Takashima M, Theelen B et al. 2015b - Phylogeny of yeasts and related filamentous fungi within Pucciniomycotina determined from multigene sequence analyses. Studies in Mycology 81, 27-53.

Wang Q-M, Theelen B, Groenewald M, Bai F-Y et al. 2014 - Moniliellomycetes and Malasseziomycetes, two new classes in Ustilaginomycotina. Persoonia 33, 41.

Wijayawardene DNN, McKenzie EHC, Hyde KD. 2012 - Towards incorporating anamorphic fungi in a natural classification-checklist and notes for 2011. Mycosphere 3, 157-228.

Wijayawardene NN, Crous PW, Kirk PM, Hawksworth DL et al. 2014 - Naming and outline of Dothideomycetes-2014 including proposals for the protection or suppression of generic names. Fungal Diversity 69, 1-55.

Wijayawardene NN, Hyde KD, Divakar PK, Rajeshkumar KC, Weerahewa D, Delgado G, Wang Y, Fu L 2018a - Notes for genera update - Ascomycota: 6616-6821. Mycosphere 9(1), 115140.

Wijayawardene NN, Hyde KD, Lumbsch HT, Liu JK et al. 2018b - Outline of Ascomycota - 2017. Fungal Diversity 88(1), 167-263.

Wijayawardene NN, Hyde KD, Rajeshkumar KC, Hawksworth DL et al. 2017a - Notes for genera: Ascomycota. Fungal Diversity 86, 1- 594.

Wijayawardene NN, Hyde KD, Tibpromma S, Wanasinghe DN et al. 2017b - Towards incorporating asexual fungi in a natural classification: checklist and notes 2012-2016. Mycosphere 8, 1457-1554.

Wijayawardene NN, Pawłowska J, Letcher PM, Kirk PM et al. 2018c - Notes for genera: basal clades of Fungi (including Aphelidiomycota, Basidiobolomycota, Blastocladiomycota, Calcarisporiellomycota, Caulochytriomycota, Chytridiomycota, Entomophthoromycota, Glomeromycota, Kickxellomycota, Monoblepharomycota, Mortierellomycota, Mucoromycota, Neocallimastigomycota, Olpidiomycota, Rozellomycota and Zoopagomycota). Fungal Diversity 92(1), 43-129. 
Zhao R-L, Li GJ, Sanchez-Ramirez S, Stata M et al. 2017 - A six-gene phylogenetic overview of Basidiomycota and allied phyla with estimated divergence times of higher taxa and a phyloproteomics perspective. Fungal Diversity 84(1), 43-74. 